\title{
PENINGKATAN KAPASITAS GURU AKUNTANSI DALAM MATA PELAJARAN AKUNTANSI LEMBAGA (Pelatihan Tata Kelola Keuangan Desa)
}

\author{
Yeni Priatna Sari ${ }^{1}$, Andri Widianto ${ }^{2}$, Moh Alfian ${ }^{3}$, \\ Ririh Sri Harjanti ${ }^{4}$, Ghea Rahmadiane ${ }^{5}$ \\ Politeknik Harapan Bersama; Jalan Mataram No 9 Pesurungan Lor - Tegal 0283 - 352000 \\ Program Studi DIII Akuntansi, Politeknik Harapan Bersama Tegal \\ e-mail: yeni.priatna@gmail.com ${ }^{1}$, andri.widi29@gmail.com ${ }^{2}$, alfian_fee20@yahoo.co.id ${ }^{3}$, \\ ririh_sri@yahoo.co.id ${ }^{4}$, ghea_unsoed@gmail.com ${ }^{5}$
}

\begin{abstract}
Abstrak
Akuntansi Lembaga atau penatausahaan keuangan desa saat ini menjadi trend di pedesaan karena adanya dana desa yang menyerap dana milyaran. Berawal dari kondisi tersebut tim Pengabdian Masyarakat Prodi Akuntansi Politeknik Harapan Bersama berinisiatif untuk memberikan pembelajaran kepada para guru SMK yang saat ini juga mengajarkan Akuntansi Lembaga ke murid SMK sebagai sarana untuk peningkatan kapasitas untuk memberikan pembelajaran kepada siswa SMK.
\end{abstract}

Kata kunci - peningkatan kapasitas, akuntansi lembaga, keuangan desa

\section{PENDAHULUAN}

Kurikulum 2013 adalah bentuk kurikulum yang baru saja di implementasikan di SMK dan sekolah sederajat. Pada Kurikulum tersebut terdapat mata pelajaran baru yaitu pelajaran Praktikum Akuntansi Lembaga / Pemerintahan. Para Guru Akuntansi masih membutuhkan banyak pelatihan untuk dapat mengembangkan bahan ajar untuk mata pelajaran praktikum akuntansi lembaga tersebut. Pengorganisasian pembelajaran Akuntansi di SMK, meliputi pengorganisasian materi pelajaran secara berurutan sesuai dengan acuan silabus, mengorganisir kalender akademik untuk pelaksanaan pelajaran praktik, mengorganisir kelas agar tidak terjadi kegaduhan dengan pengawasan dan sanksi, mengorganisir kesulitankesulitan materi pelajaran dan mencarikan penyelesaian (1).

Pengembangan bahan ajar Praktikum Akuntansi di SMK merupakan salah satu upaya yang dilakukan untuk dapat meningkatkan kompetensi siswa (2). Untuk itu pada kegiatan PKM akan memberikan peningkatan kapasitas kepada para guru Akuntansi di SMK, berupa pelatihan Akuntansi Lembaga untuk guru Akuntansi di tingkat SMK. 
Beberapa literatur tentang akuntansi desa telah digunakan dalam kegiatan pengabdian masyarakat ini. Diantaranya adalah buku Akuntansi Desa telah dijabarkan beberapa tahapan dalam proses pencatatan akuntansi desa (3). Selain itu adalah buku tentang sistem pengelolaan akuntansi yang dikeluarkan oleh Pusdiklatwas BPKP (4). Dan beberapa penelitian sebagai sumber informasi tentang bagaimana membuat materi praktikum (5). Sedangkan Undang-undang dan peraturan pemerintah yang digunakan dalam kegiatan pengabdian ini adalah (6) dan peraturan pemerintah tentang pengelolaan keuangan desa (7)

\section{METODE}

Metode kegiatan pengabdian masyarakat kali ini adalah dengan menggunakan metode pelatihan yaitu berupa pemberian materi Akuntansi Desa dan latihan soal dan memberikan kesempatan bertanya untuk semua peserta pelatihan. Setelah pemateri menyampaikan materi pelatihan, peserta juga dapat menanyakan apabila ada hal-hal yang dirasa belum dimengerti.

\subsection{Kerangka Pemecahan Masalah}



Gambar 1 Kerangka Pemecahan Masalah

\subsection{Realisasi Pemecahan Masalah}

Dana desa telah dikucurkan oleh pemerintah sejak tahun 2014. Hal tersebut membuat pemerintah desa harus mulai belajar mengelola dana yang jumlah nya tidak sedikit. Dana desa yang berjumlah sekitar 1 milyar perdesa per tahun jika tidak dimanfaatkan dan dikelola dengan baik akan berdampak pada tingkat korupsi dan penyelewengan dana yang semakin tinggi di kalangan masyarakat. Oleh karena itu salah satu pemecahan masalah pengelolaan dana desa dibantu dengan adanya kegiatan pengabdian yang dilakukan oleh tim prodi akuntansi Politeknik Harapan Bersama Tegal yaitu dengan melakukan kegiatan pelatihan pengelolaan dana desa yang dilakukan untuk para guru akuntansi di SMK. 


\section{HASIL DAN PEMBAHASAN}

\subsection{Hasil Kegiatan}

Hasil kegiatan ini adalah terlaksananya kegiatan pelatihan pengelolaan keuangan desa pada tanggal hari Jumat, 31 Januari 2019 bertempat di Ruang C 3.3 dengan pembicara Ibu Wiratna Sujarweni penulis buku Akuntansi Desa dari Pustaka Baru Press dan dihadiri oleh sekitar 23 guru akuntansi dari SMK di kota dan Kabupaten Tegal.

\subsection{Pembahasan}

Pengelolaan keuangan desa adalah kegiatan pencatatan dan pengikhtisaran transaksi keuangan desa agar dapat menghasilkan laporan keuangan desa. Saat ini laporan keuangan desa belum mempunyai standar yang ditetapkan oleh Ikatan Akuntan Indonesia. Sehingga saat ini laporan keuangan desa menggunakan aturan yang ditetapkan oleh kementerian dalam negeri saja. Adapun laporan yang dibuat adalah laporan laba rugi, laporan neraca dan laporan realisasi anggaran untuk pemerintah desa.

\section{KESIMPULAN}

Akuntansi lembaga bukanlah hal baru ketika mempelajari akuntansi keuangan. Hal yang berbeda dari akuntansi lembaga yang telah di ajarkan sebelumnya adalah pada entitasnya serta tidak adanya standar yang telah ditetapkan dari Ikatan Akuntan Indonesia. Sehingga format dan alurnya menjadi tidak seragam dan rancu. Akan tetapi dengan adanya UU No 6 Tahun 2014 tentang dana desa secara bertahap akan dilakukan evaluasi dan bertahap. Seperti akan di sosialisasikannya Standar Akuntansi Pemerintah Desa (SAPDesa) oleh pemerintah.

\section{SARAN}

Saran untuk kegiatan ini adalah di perbanyak kegiatan semacam ini dan dengan audience yang meluas, tidak hanya guru SMK tapi termasuk pengelola keuangan desa. Pelebaran peserta dapat mencakup semua kabupaten yang ada di sekeliling Kota Tegal seperti Kabupaten Tegal, Kabupaten Brebes, Kabupaten Pemalang. Karena informasi dan pendampingan semacam ini amat dibutuhkan oleh masyarakat desa. 


\section{UCAPAN TERIMA KASIH}

Puji syukur kami panjatkan kehadirat Allah SWT yang telah memberikan kesempatan kepada kami tim Dosen Program Studi DIII Akuntansi Politeknik Harapan Bersama untuk melaksanakan kegiatan pengabdian masyarakat (PKM) sebagai salah satu Tridharma Perguruan Tinggi. PKM yang dilaksanakan berjudul "Peningkatan Kapasitas Guru Akuntansi Dalam Mata Pelajaran Akuntansi Lembaga (Pelatihan Tata Kelola Keuangan Desa)". Ucapan terima kasih juga kami sampaikan kepada Ketua P3M yang telah memberikan kesempatan, para dosen sebagai anggota tim dan juga seluruh peserta guru SMK yang telah bersedia hadir dalam kegiatan tersebut.

\section{DAFTAR PUSTAKA}

[1]. Utami LR, Subadi T. Pengelolaan Pembelajaran Akuntansi di SMK. Varia Pendidik. 2016;28(1):43-50.

[2]. Wijayanti A. Model Pembelajaran Praktikum Akuntansi untuk Meningkatkan Aktivitas Belajar Mahasiswa. 2014;21:194-207.

[3]. Sujarweni W. Akuntansi Desa Panduan Tata Kelola Keuangan Desa. Pustaka Baru Press; 2014.

[4]. BPKP P. Pengelolaan Keuangan Desa. Pusdiklatwas BPKP; 2016.

[5]. Wijayanti A. Model Pembelajaran Praktikum Akuntansi untuk Meningkatkan Aktivitas Belajar Mahasiswa. 2014;

[6]. RI P. UU NOMOR 6 TAHUN 2014. 2019 p. 1689-99.

[7]. PERATURAN PEMERINTAH REPUBLIK INDONESIA. NOMOR 43 TAHUN 2014. NOMOR 43 TAHUN 20142014 p. 1-15. 